\title{
The Zarit Burden Interview in Portugal: Validity and Recommendations in Dementia and Palliative Care
}

\author{
A Escala de Sobrecarga de Zarit em Portugal: Validade e Recomendações na \\ Demência e em Cuidados Paliativos
}

Manuel GONÇALVES-PEREIRA ${ }^{1}$, Steven H. ZARIT ${ }^{2}$

Acta Med Port 2014 Mar-Apr;27(2):163-165

ABSTRACT

The impact of dementia on informal or family caregivers became a public health issue. One well-established tool for the assessment of emotional, physical and social impact on caregivers is the Zarit Burden Interview. Worldwide, it is widely used in epidemiological studies, drug or psychosocial clinical trials, and health services research. The original focus on burden among dementia caregivers has spread to other clinical contexts, mostly in old age and palliative care. Given these diverse applications, issues around the validity and reliability of national translations are crucial to assure that all evidence gathered is indeed of high quality. Moreover, caution is needed on the use of cut-offs for categorizing levels of caregiver strain or of subscales derived from recurrent exploratory factor analyses in small-scale local studies. As with other translations of measures in the health field, researchers and clinicians in Portugal must be aware of how to address bias in using the Zarit Burden Interview and interpreting findings.

Keywords: Caregivers; Dementia; Interviews as Topic; Palliative Care; Portugal; Psychometrics.

\section{RESUMO}

O impacto da demência em cuidadores informais ou familiares tornou-se uma questão de saúde pública. A escala de sobrecarga "Zarit Burden Interview" constitui um instrumento bem reconhecido de avaliação do impacto emocional, físico e social sobre os cuidadores. Tem vindo a ser utilizada em todo o mundo em estudos epidemiológicos, ensaios clínicos (farmacológicos ou psico-sociais), bem como na investigação de serviços de saúde. O enquadramento inicial na demência estendeu-se a outros contextos clínicos, principalmente em Geriatria e em Cuidados Paliativos. Dadas esta diversidade de aplicações, os aspectos envolvendo a validade e fiabilidade das traduções nacionais são cruciais para assegurar que toda a evidência obtida seja de elevada qualidade. Para além disso, é necessário cuidado na utilização de cut-offs para definir níveis de sobrecarga sobre o cuidador ou de subescalas resultantes de análises factoriais exploratórias em estudos locais de pequena escala. Tal como sucede com outras traduções de instrumentos de avaliação aplicados no âmbito dos cuidados de saúde, os investigadores e clínicos portugueses devem conhecer o modo de abordar os eventuais enviesamentos quer na utilização da "Zarit Burden Interview" quer na interpretação dos resultados obtidos.

Palavras-chave: Cuidadores; Cuidados Paliativos; Demência; Entrevistas como Assunto; Portugal; Psicometria.

\section{The Burden Interview}

The Zarit Burden Interview-ZB| ${ }^{1}$ is widely used in dementia research, including family caregiving studies, drug and psychosocial intervention clinical trials. ${ }^{2,3}$ The ZBI is a self-report questionnaire, used to assess the feelings of burden of informal caregivers regarding the impact of the disease on their lives. The questions refer to problems arising in several domains: health and well being, personal and social life and finances. The ZBI has become useful in the assessment of subjective burden in carers of dependent elderly people with diagnoses other than dementia (as depression) and in palliative care. ${ }^{4}$ On the whole, there is extensive research in frail elderly caregiving with the ZBI. This widespread use has fostered questions about comparability of findings internationally. Therefore, validity research on the ZBI across countries and cultures is crucial to the quality of epidemiological, clinical and health-services research, as well as for routine clinical practice.

In the 22-item ZBI, the items (e.g. 'are you afraid what the future holds for your relative?') are scored in Likert scales, from 0 (never) to 4 (almost always), except for the final question on global burden, rated from 0 (not at all) to 4 (extremely). The sum of individual item-scores has a range from 0 to 88 (total score). Different scorings were used (1-5 at item-level, and $22-110$ in totals) ${ }^{5}$ but, regardless of the option, higher scores mean higher burden.

Construct and concurrent validity were documented, ${ }^{1-3}$ including reports of positive correlations with time devoted to care and with depressive symptoms. ${ }^{2,6,7}$ Different factorstructures were proposed, ${ }^{5,8}$ the majority with 2 or 3 factors/ domains. Notwithstanding, most studies rely on total scores. Short/screening versions were also derived: some claim that psychometric properties may be compromised, ${ }^{2}$ although this remains controversial. ${ }^{4}$ Internal consistency is invariably good, the same applying to test-retest and interrater reliability - when the $\mathrm{ZBI}$ is used as an interview. ${ }^{1-3}$

The ZBI was translated and validated in many countries, including Brazil and Spain. In Portugal, researchers may be puzzled by the multiplicity of translations (Table 1). One of us (MG-P) co-authored a version, developed through standard translation-back translation-revision procedures, with discussion of cultural acceptability in focus groups. Huge differences are not apparent between these

1. Departamento de Saúde Mental e Centro de Estudo de Doenças Crónicas. Faculdade de Ciências Médicas. Universidade Nova de Lisboa. Lisboa. Portugal.

2. Department of Human Development and Family Studies. Penn State University. University Park. United States of America.

Recebido: 26 de Dezembro de 2013 - Aceite: 17 de Março de 2014 | Copyright @ Ordem dos Médicos 2014 
translations. The MAPI Research Trust (which holds the distribution rights for the $\mathrm{ZBI}$ ) recently issued a high-quality European Portuguese translation (Table 1), using linguisticvalidation methods that assure that nuances of meaning are accurately conveyed in the translation. ${ }^{9}$

\section{The Lisbon study on families of people with dementia (FAMIDEM)}

The rationale for a recent Portuguese study of family caregivers in dementia, FAMIDEM, was to explore several still unanswered issues, such as the importance of diseaserelated knowledge and the risks for secondary caregivers. Key-relatives (primary caregivers) usually provide the bulk of informal care, but are often helped by other relatives (secondary caregivers) who may or may not live in the same household. Furthermore, in local high-quality research, measures must be cross-culturally validated. So FAMIDEM was conducted with international collaboration, aiming to: 1. understand how caregivers' knowledge about dementia could relate to aspects of the caregiving experience, including burden; 2 . compare primary and other less directly involved caregivers; and 3 . contribute to the national validation of caregiving measures. ${ }^{7,10}$

FAMIDEM was a non-randomised cross-sectional study, conducted in three waves: the first was a pilot study, the second focused on dementia literacy issues ${ }^{7}$ and wave III regarded secondary caregiving. Outpatients with ICD10 dementia and their family caregivers were identified in neurology or psychiatric services. Caregivers were assessed for positive aspects of caregiving, distress, social support, dementia knowledge and sense of coherence. The subjective and objective components of burden were also evaluated (the former with the ZBI). No associations were found between knowledge and the other variables: many caregivers, albeit informed about dementia, were at risk of high burden and distress. ${ }^{7}$ In an exploratory analysis, two caregivers of the same patient $(n=41)$ were compared. One of these caregivers had the primary responsibility for care and the other played a supplementary role to the primary caregiver. Risks were greater for primary caregivers, but both types of caregiver reported subjective burden. Given the importance of secondary caregivers in Portugal, the findings warrant further exploration: wave III results are now under analysis.

Finally, the results contributed to establish the psychometric properties of the ZBI in Portugal, which allows for further comparative research. Face, content, ecological, discriminant and convergent validity of a Portuguese translation were documented, together with internal consistency ( $\alpha=0.88 ; n=116)$ and test-retest reliability (ICC $=0.93, \mathrm{Cl} 95 \% 0.88-0.96, p<0.001 ; n=69) .{ }^{7}$ Other groups explored convergent validity and sensitivity to change (e.g. EDUCA-II) using this version. It was included in the tool battery of the elderly neuropsychiatric disorders prevalence study, by the Nova Medical School and the 10/66 Dementia Research Group in Portugal. ${ }^{11}$
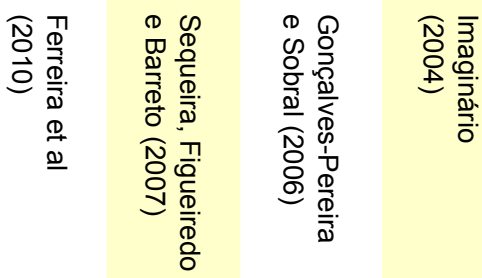

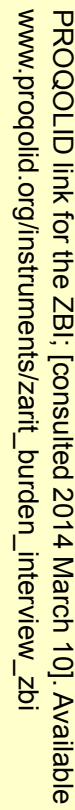

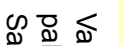

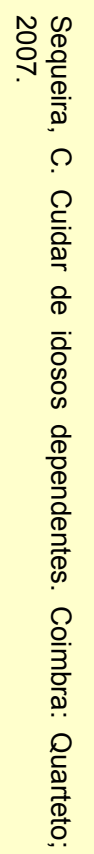

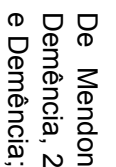

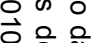

$\omega$ 虫

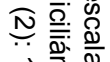

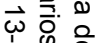

10 is $\frac{2}{10}$

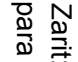

응 음

通

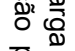

훌응

ه్

융

吝

$\stackrel{\%}{\rightleftharpoons}$

이 응

กำ

\

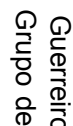

两

罂了

응 을

으 웅

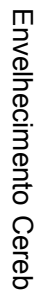

离

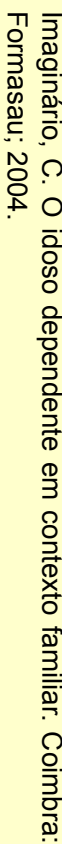


Final issues on the practical use of the $\mathrm{ZBI}$

The usefulness of the $\mathrm{ZBI}$ in populations other than the frail elderly is under discussion.

The scale has been applied in many conditions, such as depression, schizophrenia, multiple sclerosis, parkinsonism, cerebro-vascular disease, cancer or palliative care. The ZBI was not originally designed for the universal assessment of the burden of care: validity and reliability are not documented sufficiently in all populations. Thus, caution is needed on its use in these diverse groups of caregivers.

Ferreira et $\mathrm{al}^{12}$ used the $\mathrm{ZBI}$ to assess Portuguese informal caregivers in home palliative care settings, a topic of great interest in research and clinical practice. However, producing an additional translation for specific use in palliative care would not be essential, contrary to what the authors apparently suggest. In other studies of caregivers of people with cancer and acquired brain injury using the $\mathrm{ZBI}$ there was no need to change the questionnaire itself. ${ }^{4}$ We lack information on the prevalence of dementia among care recipients in the aforementioned study, ${ }^{12}$ although $\mathrm{ZBI}$ scores were apparently closer to those of Portuguese dementia caregivers ${ }^{7}$ than to those of international samples in advanced cancer. ${ }^{4}$

Concerning psychometric issues, one must also be cautious in adopting new ZBI factor-structures. Reports may come from exploratory and not confirmatory factor analyses, thus factorial solutions seldom coincide. The use of small, non-representative samples also increases difficulty in replicating factor structure.

Finally, a most important issue regards the adoption of cut-offs to define categories of lower and higher burden. A meta-analysis in heterogeneous samples reported

\section{REFERENCES}

1. Zarit SH, Reever KE, Bach-Peterson J. Relatives of the impaired elderly: Correlates of feelings of burden. Gerontologist. 1980;20:649-55.

2. Brodaty $\mathrm{H}$. Meaning and measure of caregiver outcomes. Int Psychogeriatr. 2007;19:363-81.

3. Bachner YG, O'Rourke NO. Reliability generalization of responses by care providers to the Zarit Burden Interview. Aging Ment Health. 2007;11:678-85.

4. Higginson IJ, Gao W, Jackson D, Murray J, Harding R. Short-form Zarit Caregiver Burden Interviews were valid in advanced conditions. J Clin Epidemiol. 2010;63:535-42.

5. Martín-Carrasco M, Otermin P, Pérez-Carmo V, Pujol J, Agüera L, Martín MJ, et al. EDUCA study: Psychometric properties of the Spanish version of the Zarit Caregiver Burden Scale. Aging Ment Health. 2010;14:70571.

6. Schreiner AS, Morimoto T, Arai Y, Zarit S. Assessing family caregivers' mental health using a statistically derived cut-off score for the Zarit Burden Interview. Aging Ment Health. 2006;10:107-11.

7. Gonçalves-Pereira M, Carmo I, da Silva JA, Papoila AL, Mateos R, Zarit SH. Caregiving experiences and knowledge about dementia in Portuguese clinical outpatient settings. Int Psychogeriatr. 2010;22:27080.

8. Ankri J, Andrieu S, Beaufils B, Grand A, Henrard JC. Beyond the global score of the Zarit Burden Interview: useful dimensions for clinicians. mean ZBI scores of $33.6 \pm 12.1$, reflecting considerable burden of care. ${ }^{3}$ Some authors proposed cut-offs for the interpretation of results. Hébert and colleagues defined, in a population-based study, categories of low $(<9)$, moderate (9-17), high (18-32) and severe burden (scores $\geq 33$ ), but mean scores were low in this sample. ${ }^{13}$ Scores $\geq 24$ may reflect depression, ${ }^{6}$ while Spanish researchers attempted to predict anxiety and/or depression (GHQ-caseness) through the use of ZBI cut-offs, with good sensitivity/specificity. ${ }^{5}$ However, larger sample studies are needed. It is worrisome that many cut-offs seem to have been postulated arbitrarily. For the moment, we should rely mostly on total scores and avoid categorizations related to cut-offs not yet culturally or clinically validated. Portuguese researchers should refer to previous national explorations of caregiving for global impressions on the meaning of their own results, paying attention to the clinical setting in which they were conducted (neurocognitive disorder or palliative care).

In conclusion, caution is needed on the use of cut-offs for categorizing levels of caregiver strain or on subscales derived from recurrent exploratory factor analyses in smallscale local studies. As with other translations of measures in the health field, researchers and clinicians must address bias in using the ZBI and interpreting findings.

\section{CONFLICTS OF INTEREST}

Steven $\mathrm{H}$. Zarit receives royalties from MAPI for the use of the ZBI.

\section{FUNDING SOURCES}

None stated.

Int J Geriatr Psychiatry. 2005;20:254-60.

9. Wild D, Grove A, Martin M, Eremenco S, McElroy S, Verjee-Lorenz A, et al. Principles of good practice for the translation and cultural adaptation process for patient-reported outcomes (PRO) measures: report of the ISPOR task force for translation and cultural adaptation. Value Health. 2005;8:94-104

10. Gonçalves-Pereira M, Zarit SH, Mateos R. The Lisbon study on families of people with dementia (FAMIDEM). WASP 2013. Proceedings of the $21^{\text {st }}$ World Congress of Social Psychiatry, World Association of Social Psychiatry, Lisbon 2013 June 29-July 3. Lisbon: WASP; 2013. p.198.

11. Gonçalves-Pereira M, Cardoso AM, Verdelho A, Alves da Silva J, Gens P, Raminhos C, et al. The 10/66-Dementia Research Group prevalence study in Portugal: preliminary results (2012). Psychother Psychosom. 2013;82:S37.

12. Ferreira F, Pinto A, Laranjeira A, Pinto AC, Lopes A, Viana A, et al. Validação da escala de Zarit: sobrecarga do cuidador em cuidados paliativos domiciliários para população portuguesa. Cad Saúde. 2010;3:13-9.

13. Hébert R, Bravo G, Préville M. Reliability, validity and reference values of the Zarit Burden Interview for assessing informal caregivers of community-dwelling older persons with dementia. Can J Aging. 2000;19:494-507. 


\section{The Zarit Burden Interview in Portugal: Validity and Recommendations in Dementia and Palliative Care \\ Acta Med Port 2014:27:163-165}

Publicado pela Acta Médica Portuguesa, a Revista Científica da Ordem dos Médicos

Av. Almirante Gago Coutinho, 151

1749-084 Lisboa, Portugal.

Tel: +351218428215

E-mail: submissao@actamedicaportuguesa.com

www.actamedicaportuguesa.com

ISSN:0870-399X | e-ISSN: 1646-0758

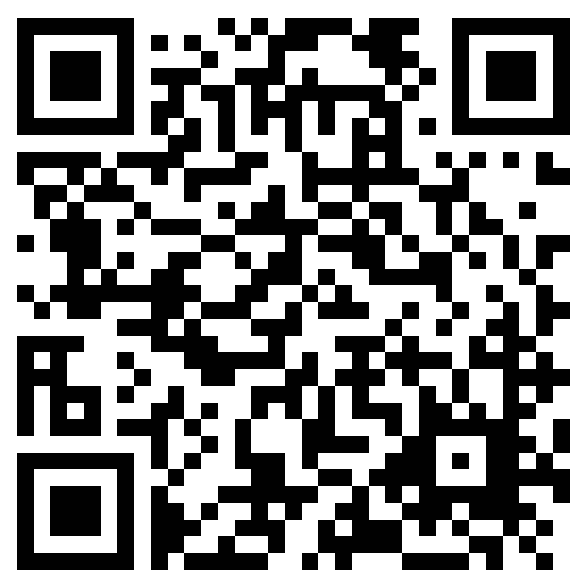

